DOI https://doi.org/10.17308/vsu.proc.law.2021.1/3314

\title{
РАЗВИТИЕ АДМИНИСТРАТИВНОГО ЗАКОНОДАТЕЛЬСТВА В РЕСПУБЛИКЕ КАЗАХСТАН: НОВЫЙ КОДЕКС
}

\author{
Р. А. Подопригора \\ Каспийский общественный университет \\ Поступила в редакцию 10 января 2021 г.
}

\begin{abstract}
Аннотация: рассматриваются основные положения принятого в Республике Казахстан Адлинистративного процедурно-процессуального кодекса. Раскрываются новелль законодательства приленительно к институтал административных процедур и адлинистративного процесса (судопроизводства), а также показываются возможные проблель в правоприменительной практике. Высказывается предположение, что без серьезных изленений в политико-правовой систеле и в правовой психологии кодекс может оказаться невостребованнылм.

Ключевые слова: Республика Казахстан, адлинистративные процедуры, административный процесс (судопроизводство).
\end{abstract}

\begin{abstract}
Administrative Procedural-Process Code adopted in the Republic of Kazakhstan. The author shows the new legislative provisions in respect of administrative procedures and administrative process as well as possible problems of law-enforcement practice. It is suggested that the Code may be unclaimed without serious changes in political-legal system and legal psychology.
\end{abstract}

Key words: Republic of Kazakhstan, administrative procedures, administrative process.

Президентом Республики Казахстан 29 июня 2020 г. был подписан Административный процедурно-процессуальный кодекс Республики Казахстан ${ }^{1}$ (далее - АППК). Тем самым закончилась долгая эпопея с нормативным закреплением двух важнейших институтов административного права: административных процедур и административного процесса (административного судопроизводства).

Примерно с начала XX в. в Казахстане велись разговоры о разработке соответствующих нормативных правовых актов. И некоторые даже появились. Например, еще 27 ноября 2000 г. был принят Закон «Об административных процедурах» ${ }^{2}$. Но этот очень лаконичный закон был далек от классических вопросов административных процедур, сосредоточенных вокруг издания так называемых административных актов. Хотя и объявлялось, что он регулирует порядок принятия и исполнения решений при осуществлении государственными органами и должностными лицами государственных функций и должностных полномочий и их оформ-

\footnotetext{
${ }^{1}$ Казахстанская правда. 2020. 30 июня.

${ }^{2}$ Ведомости Парламента Республики Казахстан. 2000. № 20. Ст. 379.

(C) Подопригора Р. А., 2021
} 


\section{Вестник ВГУ. Серия: Право}

ление, но этим вопросам отводилось всего пять статей, а остальные были посвящены процедурам работы государственного аппарата, рассмотрения обращений граждан, включая жалобы, принятия решений в области экономики. Гораздо детальнее процедуры развивались в отраслевом, регистрационном, разрешительном, контрольно-надзорном и ином законодательстве. В 2014-2015 гг. был подготовлен новый проект закона об административных процедурах, который планировалось внести в Парламент. Но параллельно готовился закон о правовых актах ${ }^{3}$, который в итоге включил в свой предмет и вопросы правовых актов индивидуального применения - сердцевину административных процедур.

Что касается административного судопроизводства, то в 2010 г. в Парламенте рассматривался проект Административного процессуального кодекса, который объединил в себе производство по рассмотрению дел об административных правонарушениях и производство по рассмотрению публично-правовых споров между государством и негосударственными субъектами. Несовместимость таких производств в одном акте послужила главной причиной отзыва кодекса Правительством из Мажилиса (нижней палаты) Парламента. Еще один проект Административного процессуального кодекса был разработан Верховным Судом Республики Казахстан в 2015 г., но он также не нашел своего логического завершения.

В итоге в 2018 г. было принято решение о подготовке Административного процедурно-процессуального кодекса Республики Казахстан. Основными его разработчиками являлись Министерство юстиции (в части административных процедур) и Верховный Суд (в части административного процесса). C самого начала его сложное название вызывало вопросы, особенно в части административного процесса. Несмотря на то что в науке административного права представление об административном - процессе является одним из самых спорных и неоднозначных ${ }^{4}$, инициаторы законопроекта решили закрепить в названии этот вид процесса. Но это связано скорее не с убежденностью разработчиков в правильности юстиционного подхода к пониманию административного процесса, а с необходимостью выбора названия, более-менее соответствующего содержанию. В отличие от России, где, как отмечает Ю. Н. Старилов, присутствовал долгий, трудный, наполненный непримиримыми спорами, «борьбой» различных научных школ, ученых - представителей различных отраслей материального и процессуального права, противопоставленными

${ }^{3}$ О правовых актах : закон Республики Казахстан от 6 апреля 2016 г. // Ведомости Парламента Республики Казахстан. 2016. № 7-І. Ст. 46.

${ }^{4}$ См.: Жанузакова Л. Т. Понятие и признаки административно-процессуальных правоотношений // Вестник Института законодательства Республики Казахстан. 2019. № 1. С. 22-24 ; Зеленцов А. Б., Кононов П. И., Стахов А. И. Административный процесс как вид юридического процесса : современные проблемы понимания и нормативно-правовой регламентации // Вестник Санкт-Петербургского гос. ун-та. Серия: Право. 2018. Т. 9, вып. 4. С. 501-521 ; Панова И. В. Развитие административного судопроизводства и административной юстиции // Право. Журнал Высшей школы экономики. 2017. № 1. С. 39 ; и др. 
научными позициями период обсуждения идеи создания полноценной системы административного судопроизводства ${ }^{5}$, в Казахстане акты готовились и принимались спорадически, без серьезного научного осмысления очень сложных правовых институтов.

Когда появился окончательный текст акта, возникли вопросы, почему был выбран такой вид акта, как кодекс. Административное право получило еще один кодифицированный акт, но выбор такой фоормы правотворчества и систематизации законодательства спорный. Объединить в один акт два действительно важных института, причем в усеченном виде (как будет показано ниже), без переработки всего законодательного массива, это еще не значит произвести кодификацию. Сам кодекс по своему объему оказался одним из самых маленьких среди других кодифицированных актов.

Важно отметить, что оба института и административных процедур, и административного судопроизводства разрабатывались на основе немецкого опыта правового регулирования. Очень активным в этом процессе являлось Германское общество по международному сотрудничеству (GIZ), организующее большое количество конференций, семинаров, зарубежных поездок представителей государственных органов, исследовательских организаций, ученых для ознакомления с опытом других стран. Во многом благодаря деятельности GIZ были приняты соответствующие нормативные правовые акты в других странах Центральной Азии, а Казахстан стал последней страной, где появились эти институты в их современном понимании ${ }^{6}$.

\section{Административные процедуры}

Кодекс говорит о двух видах административных процедур: внутренних и внешних.

Внутренние процедуры связаны с единоличной распорядительной деятельностью должностного лица или деятельностью коллегиального государственного органа, вопросами организации государственного органа, внутреннего порядка рассмотрения, прохождения служебных документов и внутреннего контроля за их исполнением, информационным обменом между государственными органами, а также осуществлением передачи государственных фрунций в конкурентную среду.

Во время обсуждения кодекса была определенная дискуссия, должны ли такие процедуры подпадать под регулирование АППК. В зарубежной практике административные процедуры чаще всего связаны с изданием административных актов, т. е. с внешней, а не с внутриорганизационной

${ }^{5}$ См.: Старилов Ю. Н. Административные процедуры, административное судопроизводство, административно-деликтное право : три основных направления модернизации российского законодательства // Ежегодник публичного права 2015 : Административный процесс. М., 2015. С. 303.

${ }^{6}$ См.: Подопригора Р. А. О проблемах проекта Административного процедурно-процессуального кодекса Республики Казахстан // Научные труды «Әділет». 2019. № 4. C. 20. 


\section{Вестник ВГУ. Серия: Право}

деятельностью государственных органов. Но этот аргумент не был воспринят, в том числе по причине несколько искусственного «дотягивания» содержания проекта до кодифицированного акта.

В АППК, кстати, содержатся понятия государственного органа, конкурентной среды, мониторинга переданных функций, должностного лица, оптимизации государственных органов, уполномоченного органа в сорере развития системы государственного управления и многие другие положения, не имеющие прямого отношения к классической административной процедуре.

Внешняя административная процедура (административная процедура) - деятельность административного органа, должностного лица по рассмотрению административного дела, принятию и исполнению по нему решения, совершаемая на основании обращения или по собственной инициативе, а также деятельность, осуществляемая в порядке упрощенной административной процедуры.

Под упрощенной административной процедурой понимается рассмотрение сообщений, предложений, откликов и запросов, не связанных с изданием административного акта. Эти вопросы в настоящее время регулируются Законом Республики Казахстан от 12 января 2007 г. «О порядке рассмотрения обращений физических и юридических лиц».

Ключевыми новеллами института административных процедур являются:

- новые принципы таких процедур: справедливость, соразмерность, охрана права на доверие, запрет злоупотребления формальными требованиями, презумпция достоверности, административное усмотрение;

- понятие административного органа. Таким органом может быть не только государственный орган, орган местного самоуправления, но и го-

- сударственное юридическое лицо, а также иная организация, которые 일 наделены полномочиями по принятию административного акта, совершению административного действия (бездействия). То есть административным органом может признаваться даже негосударственная организация, если ей переданы определенные государственные полномочия;

- нормативное закрепление понятия административного акта и ад-

140 министративного действия (бездействия). Под административным актом понимается решение, принимаемое административным органом, должностным лицом в публично-правовых отношениях, реализующее установленные законами права и обязанности определенного лица или индивидуально определенного круга лиц, а под административным действием (бездействием) - действие (бездействие) административного органа, должностного лица в публично-правовых отношениях, не являющееся административным актом;

- деление административных актов на благоприятные (акт, реализующий право участника административной процедуры или прекращающий возложенную на него обязанность, а также иным образом улучшающий его положение) и обременяющие (акт, отказывающий в реализации, 
ограничивающий, прекращающий право участника административной процедуры или возлагающий на него обязанность, а также иным образом ухудшающий его положение);

- регламентация издания административных актов. В кодексе определены формы актов, требования к их содержанию, доведению до участника процедуры, вступлению в силу, введению в действие и прекращению действия;

- установление оснований отмены законных и незаконных административных актов. Как и во многих других актах об административных процедурах, основания отмены актов связаны с принципом охраны права на доверие. То есть фризическое или юридическое лицо - адресат акта - вправе рассчитывать, что акт издан законно и, соответственно, не может быть отменен в силу вдруг возникшей необходимости или других причин. В АППК перечислены случаи, когда принцип охраны права на доверие не будет действовать (неконституционность правового акта, на основании которого был вынесен административный акт, заведомая недостоверность документа либо сведений, представленных участником административных процедур; совершение участником процедуры противоправных действий; угроза государственным или общественным интересам, безопасности государства, тяжких необратимых последствий для жизни, здоровья людей; принятие акта с условием и др.). Положения об отмене актов, особенно незаконных, вызвали, наверное, самую бурную дискуссию в процессе обсуждения. Многие были несогласны с тем, что незаконные административные акты отменить нельзя, даже принимая во внимание принцип охраны права на доверие. Но разработчикам удалось доказать, что конкуренция двух принципов: законности и охраны права на доверие это нормальное явление. Во многих правовых порядках такой конфликт присутствует, но как раз положения законов об административных процедурах позволяют его разрешить;

- закрепление очень важных процедурных прав участников административной процедуры, главным из которых является право на заслушивание. Административный орган, должностное лицо обязаны предоставить возможность участнику административной процедуры выразить свою позицию к предварительному решению по административному делу. Конечно, предусмотрен целый ряд исключений, когда заслушивание не проводится, например, если издается благоприятный акт или когда требуется незамедлительное принятие административного акта в целях защиты прав, свобод граждан и юридических лиц, общественных или государственных интересов.

Кроме того, у заявителя и заинтересованного лица (участников административной процедуры) появились права получить от административного органа разъяснение о его правах и обязанностях по вопросам, связанным с осуществлением административной процедуры; ознакомиться с административным делом, делать выписки и снимать копии как в ходе, так и после рассмотрения административного дела; в ходе обжалования 
представлять доказательства и участвовать в их исследовании, иметь представителя и др.

Главная проблема в этой части АППК связана с тем, что указанные и многие другие правильные процедурные положения рискуют остаться невостребованными. Во-первых, в первой статье кодекса говорится, что особенности осуществления административных процедур устанавливаются законами Республики Казахстан. Особенностей действительно много, поскольку много и процедур в различных законах. Но далее в кодексе говорится, что АППК регулирует отношения, связанные с осуществлением административных процедур в части, не урегулированной законами. Очень странная характеристика для кодекса. То есть АППК действует по остаточному принципу. Ему остаются только те вопросы, которые не урегулированы законами. Но, как уже выше было сказано, процедуры сегодня содержатся в большом количестве нормативных правовых актов. В стране бурно развивается институт государственных услуг, в рамках которого государственные органы также издают административные акты, но который совершенно не корреспондирует с АППК. Можно предположить, что многие процедуры просто выпадут из-под действия АППК, а в правоприменительной практике государственные органы при таких неоднозначных положениях забудут об АППК и содержащихся в нем правозащитных процедурах.

В последней статье кодекса, правда, говорится о необходимости проведения работы по приведению других актов, регламентирующих административные процедуры, в соответствие с АППК. Но такое положение звучит как лозунг и не обязывает проделывать огромную работу по ревизии всего процедурного законодательства. А такая ревизия, на наш взгляд, должна была быть сделана до принятия кодекса. Поскольку этого не произошло, то возникает риск, что административные процедуры не станут «фундаментом для построения юридической системы охраны прав, свобод и законных интересов граждан в сфере административных и иных публичных правоотношений ${ }^{7}$.

Есть и другие проблемы процедурной части АППК: очень скудные положения об исполнении административного акта, регулирование вопросов, не имеющих прямого отношения к процедурам, неоднозначные фрормулировки. Трудно предсказать, как будет действовать новый институт административного усмотрения, когда административный орган сможет выбирать одно из возможных решений. Но главной проблемой все-таки представляется сфера действия процедурной части АППК, в том числе принимая во внимание развивающиеся в государственном управлении информационные технологии, активно проникающие и в процедурную деятельность.

${ }^{7}$ См.: Старилов Ю. Н. Системное взаимодействие административного судопроизводства и административных процедур как важнейший фактор модернизации российского административного права // Модернизация административного законодательства (цели, задачи, принципы и актуальные направления) / отв. ред. А. Ф. Ноздрачев. М., 2018. С. 325. 


\section{Административный процесс}

Вторая большая часть АППК связана с рассмотрением публично-правовых споров. Именно это понимается под административным процессом. В самом тексте кодекса вместо административного процесса часто говорится об административном судопроизводстве.

Как и во многих других подобных актах, принятых на постсоветском пространстве, производство по делам об оспаривании решений и действий (бездействия) органов государственной власти, местного самоуправления, должностных лиц и государственных служащих было изъято из Гражданского процессуального кодекса и стало основным видом производства в новом кодексе.

Помимо этого основные новеллы в этой части АППК связаны со следующим:

- создание системы новых административных судов. В настоящее время в Казахстане уже действуют административные суды. Но они занимаются рассмотрением дел об административных правонарушениях. Эти суды будут переименованы в суды по административным правонарушениям. А вновь создаваемые административные суды будут рассматривать исключительно публично-правовые споры. На областном и республиканском уровне каких-либо специализированных коллегий создаваться не будет. Дела будут пересматриваться коллегией, которая занимается гражданскими делами (областной уровень) либо специализированной коллегией Верховного Суда, которая занимается инвестиционными спорами и делами об административных правонарушениях;

- новые принципы судопроизводства: справедливость, активная роль суда, разумный срок. Особенно много в процессе подготовки АППК говорилось о принципе активной роли суда, заключающегося в том, что суд, не ограничиваясь объяснениями, заявлениями, ходатайствами участников административного процесса, представленными ими доводами, доказательствами и иными материалами административного дела, всесторонне, полно и объективно исследует все фактические обстоятельства, имеющие значение для правильного разрешения административного дела. Судья вправе высказать свое предварительное правовое мнение по правовым обоснованиям, относящимся к фактическим или юридическим сторонам административного дела. Суд по собственной инициативе или мотивированному ходатайству участников административного процесса собирает дополнительные материалы и доказательства. Справедливости ради следует сказать, что об изменении роли суда в плане его активизации в сборе и исследовании доказательств заговорили и в отношении гражданского процесса

- новый подход к формированию участников административного процесса: истец, ответчик, заинтересованное лицо и прокурор. По поводу участия прокурора в административном процессе возникла серьезная

${ }^{8}$ См.: Таймерденов М. Объективно, законно и в срок // Казахстанская правда. 2020. 11 июня. 


\section{Вестник ВГУ. Серия: Право}

дискуссия. Необходимость вмешательства еще одного государственного органа в спор между гражданином и государством подвергалась сомнению. Но в итоге прокурор остался в процессе, правда, по определенным делам: налоговые, таможенные, экологические, избирательные, по делам лиц, которые в силу фризических, психических и иных обстоятельств не могут самостоятельно осуществлять защиту;

- закрепление понятия «административный иск» - требование, поданное в суд с целью защиты и восстановления нарушенных или оспариваемых прав, свобод или законных интересов, вытекающих из публично-правовых отношений;

- закрепление видов административного иска. В АППК предусмотрены четыре вида иска: об оспаривании, о принуждении, о совершении действия и о признании. Иски об оспаривании и о принуждении связаны с административными актами; о совершении действия соответственно с действием. Три этих иска не вызывают особых проблем в понимании. Четвертый иск - о признании - самый необычный. Он взят из немецкой системы административных исков. По иску о признании истец может потребовать признать наличие или отсутствие какого-либо правоотношения, если он не может воспользоваться другими исками, в том числе в связи с пропущенными сроками на подачу иска. Немецкие авторы в качестве примеров споров по таким искам называют споры о том, надо ли, в принципе, разрешение государственного органа для занятия определенным видом деятельности (общий иск о признании) или оспаривание запрета на проведение собрания, когда акт утратил силу, но сохранился интерес истца в установлении неправомерности уже исполненного административного акта (продолженный иск о признании) ${ }^{9}$. Можно предположить, что в местной практике такие иски могут быть связаны, к примеру,

- с признанием права на социальные выплаты;

- установление обязательного досудебного рассмотрения спора в вышестоящем органе;

- возможность использования примирительных процедур в публично-правовых спорах;

- возложение бремени доказывания на административный орган в

исках об оспаривании. В других исках бремя доказывания может нести как ответчик (административный орган), так и истец, в зависимости от обстоятельств дела.

Основной проблемой в данном случае является то, что АППК опять не является стержневым актом. Помимо него судьям придется пользоваться и ГПК. В ч. 3 ст. 1 говорится, что в административном судопроизводстве применяются положения Гражданского процессуального кодекса Республики Казахстан, если иной порядок не предусмотрен АППК. Объясняется это так называемой процессуальной экономией: нет смысла дубли-

${ }^{9}$ См.: Пуделька Й. Виды иска в административном судопроизводстве на примере Германии // Ежегодник публичного права - 2015 : Административный процесс. М., 2015. С. 211. 
ровать в АППК хорошо себя зарекомендовавшие положения ГПК. Очень странный, на наш взгляд, подход, в том числе с учетом того, что речь идет о новом кодифицированном акте, который, как было сказано выше, и так очень небольшой по размеру. Замах на отдельный вид судопроизводства предполагает детальное описание правил этого судопроизводства в соответствующем акте. В противном случае это судопроизводство оказывается каким-то ущербным.

Очень спорный подход обнаруживается в вопросах конкретных производств, рассматриваемых по АППК. В первую очередь, это стандартное производство по оспариванию актов, действий (бездействия) административных органов, а также производства, связанные с защитой избирательных прав граждан и участием граждан в уголовном процессе в качестве присяжного заседателя. В ГПК остались и другие производства, которые по своей природе тяготеют или однозначно являются публично-правовыми: производство об оспаривании нормативного правового акта; производство по делам о направлении несовершеннолетних в организацию образования с особым режимом содержания; производство о признании организации или информационных материалов экстремистскими; производство о принудительной госпитализации, производство о выдворении иностранца и др.

Самое популярное объяснение невключения таких производств в АППК заключается в том, что классическая административная юстиция рассматривает только споры по иску гражданина, а указанные выше производства инициируются государством. Но эта классическая юстиция формировалась и развивалась в других правовых порядках и в другие времена, когда и государство, и гражданин, и отношения, и проблемы между ними были иными. Опыт некоторых стран, близких к Казахстану по правовым традициям, показывает, что подобные особые производства охватываются современными актами об административном судопроизводстве. В частности, нам кажется, что более правильный подход применяется в Кодексе административного судопроизводства Российской Федерации, в котором сосредоточены все производства публично-правового характера. Как отмечает А. Б. Зеленцов, основной массив споров, как правило, инициируется частными лицами, но нельзя исключать случаи, когда административный спор инициируется органом публичной власти ${ }^{10}$. Перенос в АППК из ГПК всех публично-правовых производств был бы также логичным и уместным и выполнял бы одну из задач кодифицированного акта.

Кодекс вводится в действие с 1 июля 2021 г., т. е. через год после вступления в силу. Время дано для подготовки и системы государственной администрации к новым процедурным правилам и для подготовки судебной системы к новому виду судопроизводства. Предполагается, что через

${ }^{10}$ См.: Зеленцов А. Б. Административная юстиция. Общая часть. Теория судебного административного права : учеб. пособие для студ. вузов, обучающихся по специальности «Юриспруденция». М., 2015. С. 173-174. 
год государственные служащие будут в своей деятельности учитывать правозащитные административные процедуры, а судьи будут хорошо разбираться в вопросах государственного управления и не будут бояться принимать решения не в пользу государства. Есть такие ожидания. Но есть опасения, что АППК будет жить своей жизнью, не особенно сказываясь на качестве государственного управления и отправления правосудия. Опыт других центральноазиатских стран, где приняты подобные акты, подтверждает эти опасения. Очевидно, что дело не просто в принятии АППК, который собственно сам оставляет желать лучшего. Дело в более глубоких изменениях и в политико-правовой системе, и в правовой психологии.

Каспийский общественный универcumem

Подопригора Р. А., доктор юридических наук, профбессор Высшей школь права "Әділет"

E-mail:sakner@gmail.com
Caspian Public University

Podoprigora R. A., Doctor of Legal Sciences, Professor of Adilet Law School E-mail:sakner@gmail.com 